\title{
BUDDHA BIHAR (KIYANG) BASED TRADITIONAL MODEL FOR TREE DIVERSITY CONSERVATION IN RANGAMATI HILLS, BANGLADESH
}

\author{
Mohiuddin, M. and A. K. Paul \\ Bangladesh Forest Research Institute, Post Box No. 273, Chittagong 4000, Bangladesh
}

\begin{abstract}
This paper describes Buddha Bihar (Kiyang) based biodiversity conservation of Nirbanpur in Rangamati Hill District of Bangladesh. Rangamati is the native of the tribal people specially the Chakma and they are the followers of the Bhudda religion. This Bihar comprised of 300 acres of hilly land and maintaining natural patches having 76 indigenous tree species. Most of the tribal people of this district belong to Buddha religion and they strongly believe in the biodiversity conservation around their religious institute and most of them are situated at hill top of the deep forest areas. This institution is maintained by the religious leaders locally called as Bantheya and the local community people have great respect for them. Most of the Bantheyas are conserving biodiversity in traditional way which is unique model for local level biodiversity conservation and local people also consider these plants as taboos or secrete trees. Bihar management committee maintains some traditional rules in plant conservation, but now they are leaned towards commercial plantation. BFRI scientists try to motivate them towards plantation indigenous species by awareness meeting. The seedlings of 32 indigenous tree species were planted in the Bihar area which has enhanced the diversity of flora and fauna. A biodiversity conservation model having four pillars has been developed on consultation with the community and religion leaders. The theme of pillars are land tenure, traditional knowledge, awareness and support. Bihar based biodiversity conservation effort has created a new avenue for wildlife and bird conservation. A list of existing plants species around Nirbanpur Bihararea has been given.
\end{abstract}

Key words: Biodiversity conservation, Buddha-Bihar (Kiyang), Rangamati, Participatory map

\section{INTRODUCTION}

Chittagong Hill Tracts region comprises three Hill Districts, such as Khagrachari, Rangamati, and Bandarban. The hilly region covers an area of 13,295 square kilometers in southeastern Bangladesh and border India and Myanmar. This is about ten percent of the country's land surface area. Rangamati is a district in South-eastern Bangladesh. It is a part of the Chittagong Hill Tracts and the town of Rangamati serves as the headquarters of the district. Area-wise, Rangamati is the largest district of the country. The area of the district is $6116 \mathrm{~km}^{2}$ of which $1292 \mathrm{~km}^{2}$ is riverine and $4825 \mathrm{~km}^{2}$ is under forest vegetation.

The flora of Chittagong hill forests is generally uneven-aged and multi-storied forest (Alam 2008) is closely related to Indo-China than any other forest of this region (Das and Alam 2001). Clear felling of natural forest caused serious harm to natural regeneration, seedling and sapling establishment, soil fertility, natural forest condition and hence the natural ecosystem (Haque and Alam 1988). Bangladesh is severely disturbed and degraded due to rapid population growth, poverty, inappropriate forest management system, over exploitation, energy deficit and lack of motivation regarding biodiversity conservation (Hassan 1995). The overall forest structure has changed by such disturbances (Shaforth $e t$ al. 2002) which ultimately affects the nature (Kwit and Platt 2003).Global biodiversity loss has become a major political and social concern (Lele et al. 2010) and in situ conservation as the model adopted to reduce biodiversity loss (Eken et al. 2004).

In situ conservation culturally liked traditional method of germplasm management can facilitate both exploitation of genetic variability and the maintenance of desirable genotype for future plant breeding (Bellon and Brush 1994, Brush 1991, Soleri and Smith 1994). Important wild species are conserved in a natural pocket by different agencies (Rajendran et al. 1997; Biswas 1990). In situ conservation is the most powerful strategies to protect biological diversity at local level as natural reserve or conservation land (Primack 1998). The tribal people of Chittagong Hill Tracts have long heritage of using ethno- 
medicinal plants for their health care. So a good number of plants are cultivated and conserved in their in the homesteads.

The common medicinal plants conserved by the tribal people are Alpinia conchigera, Anisomeles indica, Baliospermum montanum, Centella asiatica, Costus speciosus, Jasminum scandens, Kaempferia galanga, Kaempferia parviflora, Kalanchoe pinnata, Maesa montana, Mikania cordata, Ocimum gratissimum, Oroxylum indicum, Plumbago indica, Plumbago zeylanica, Sterculia villosa, Typhonium trilobatum, Urena lobata and Zingiber montanum (Yusuf et al. 2006). Besides this Alam (1992), Rahman (1997), Rahman et al. (1998), Yusuf et al. (2002), Chakma et al. (2003), Rahman et al. (2003), Uddin and Rahman (1998), Uddin et al. (2004), Yusuf et al. (2005 2006), Mohiuddin et al. (2011) and Mohiuddin et al. (2012) also documented ethno-medicinal plants used by the tribal people of Chittagong Hill Tracts.

Biodiversity conservation is one of the vital issues on the national and international agenda for future generations. Religion, being a powerful mechanism for convincing people, has always been used for meeting the desired objectives of the society. The different religious philosophies have contributed significantly to the conservation of forests and biodiversity by their customary norms, practices and beliefs. Sacred groves are the religious practice of conserving biodiversity with strong beliefs, customs and taboos (Lakanavichian 2000). The concept of religious institution based biodiversity conservation is still relevant and exists today, especially in many parts of Thailand, Japan and other south East Asian countries (Lakanavichian 2000).

In Thailand and south East Asian countries the religion leaders working with local people to protect local biodiversity. Buddhist principles result in harmonious living within nature, and no destruction of ecosystem, and also including biodiversity conservation (Lakanavichian 2000). Harmonious relationship between humans and nature can be achieved by a combination of the recognition of human's unique position in nature together with the ideal of spiritual development and humility towards nature (Sandell 1987).

Buddha-Bihar is the religious institution for the followers of Buddha. Most of the Buddha-Bihar of Rangamati Hill District is situated at the top of the hills. Establishing the Buddha Bihar the religion leaders and local people do not cut any species from the Buddha-Bihar areas. The Buddha Bihar is kept in a comparatively undisturbed condition, due to religious belief of the local people. If they cut any trees, and flowers and fruits are plucked the lord Buddha would be offended. So, Buddha- Bihar is an ideal center for biodiversity conservation.

\section{MATERIAL AND METHODS}

The study was conducted in Buddha-Bihar in Rangamati Hill District such as Nirbanpur Bona-Bihar, Kutubchari Bono-Bihar and Khamarpara Adarsh Bono-Bihar. The list of the common plant species was made by transect walk in the study area along with the local people. The specimens of unknown species were collected and identified comparing with the authentic samples of the Bangladesh Forest Research Institute Herbarium. Information on plantation species selection, site map preparation, traditional knowledge were collected using PRA tools, field visits, observations, group discussions with religious leaders and local community elderly people (Chambers 1992).

\section{RESULTS AND DISCUSSION}

\section{Religion-based mobilization strengthen conservation}

Religious beliefs are powerful mechanism for biodiversity conservation. There is no organization to integrate the traditional knowledge with plant diversity management. Although major, the efforts by scientists and conservation organizations to conserve biodiversity have proven insufficient in decreasing biodiversity loss. All individuals have values, attitudes, motivations and these are often based in and sacred by religious beliefs. Religion is a powerful influence on human behaviour, guiding thought processes and daily living for over 80 percent of the global population (Rappaport 1979, 1999, Higgins 2011). 
Listing of the existing tree species around the Bihar

Listing of the existing tree species was made before plantation program (Table 1). This will give the real picture of biodiversity change due to plantation program.

Table 1. List of the existing plant species around the Nirbanpur Bihar area.

\begin{tabular}{|c|c|c|c|}
\hline Local name & Family & Scientific Name & Habit \\
\hline Apang & Amaranthaceae & Achyranthes aspera & Herb \\
\hline Fulkuri & Asteraceae & Aegeratum conyzoidese & Herb \\
\hline Chakua koroi & Fabaceae & Albizia chinensis & Tree \\
\hline Kalakoroi & Fabaceae & A. lebbeck & Tree \\
\hline Tetuiakoroi & Fabaceae & A. odoratissima & Tree \\
\hline Silkoroi & Fabaceae & A procera & Tree \\
\hline Chatim & Apocynaceae & Alostonia scholaris & Tree \\
\hline Kajubadam & Anacardiaceae & Anacardium occidentale & Tree \\
\hline Itchri & Combretaceae & Anogeissus acuminate & Tree \\
\hline Pitraj & Meliaceae & Aphanamixis polystachya & Tree \\
\hline Agar & Thymelaeaceae & Aquilaria agallocha & Tree \\
\hline Neem & Meliaceae & Azadirachta indica & Tree \\
\hline Supari & Arecaceae & Areca triandra & Tree \\
\hline Chapalish & Moraceae & Artocarpus chama & Tree \\
\hline Kanthal & Moraceae & A. heterophyllus & Tree \\
\hline Bartha & Moraceae & A. lacucha & Tree \\
\hline Simul & Malvaceae & Bombax ceiba & Tree \\
\hline Bon-simul & Malvaceae & B. insigne & Tree \\
\hline Barmala & Lamiaceae & Callicarpa tomentosa & Small tree \\
\hline Sonalu & Fabaceae & Cassia fistula & Tree \\
\hline Lebu & Rutaceae & Citrus grandis & Shrub \\
\hline Bhat & Lamiaceae & Clerodendrum viscosum & Shrub \\
\hline Golla bet & Arecaceae & Daemonorops jenkinsianus & Climber \\
\hline Kishnachura & Fabaceae & Delonix regia & Tree \\
\hline Bhittya garjan & Dipterocarpaceae & Dipterocarpus costatus, & Tree \\
\hline Teliya garjan & Dipterocarpaceae & D. turbinatus & Tree \\
\hline Belfoi & Elaeocarpaceae & Elaeocarpurs rugosus & Tree \\
\hline Jalpai & Elaeocarpaceae & E. floribundus & Tree \\
\hline Bot, Jhiri bot & Moraceae & Ficus benghalensis & Tree \\
\hline Bara jhiri bot & Moraceae & F. benjamina, & Tree \\
\hline Ashwathwa & Moraceae & F. religiosa & Tree \\
\hline $\mathrm{Kau}$ & Clusiaceae & Garcinia cowa & Tree \\
\hline Kannyari & Rubiaceae & Gardenia coronaria & Small tree \\
\hline Bhadi & Burseraceae & Garuga pinnata & Tree \\
\hline Gliricidia & Fabaceae & Gliricidia sepium & Tree \\
\hline Gamar & Lamiaceae & Gmelina arborea & Tree \\
\hline Assar & Malvaceae & Grewia nervosa & Tree \\
\hline Chaul mugra & Achariaceae & Gynocardia odorata & Tree \\
\hline Telsur & Diptercarpaceae & Hopea odorata & Tree \\
\hline Lambu & Meliaceae & Khaya anthotheca & Tree \\
\hline Jaial-bhadi & Anacardiaceae & Lannea coromandelica & Tree \\
\hline Menda & Lauraceae & Litsea monopetala & Tree \\
\hline Bura & Euphorbiaceae & Macaranga denticulate & Tree \\
\hline Mahua & Sapotaceae & Madhuca indica & Tree \\
\hline Kamela & Euphorbiaceae & Mallotus roxburghii & Tree \\
\hline Am & Anacardiaceae & Mangifera indica & Tree \\
\hline Uriam & Anacardiaceae & Mangifera sylvatica & Tree \\
\hline Ghoranim & Meliaceae & Melia sempervirens & Tree \\
\hline Champa & Magonliaceae & Michelia champaca & Tree \\
\hline Bakul & Sapotaceae & Mimusops elengi & Tree \\
\hline Dakroom & Rubiaceae & Mitragyna parvifolia & Tree \\
\hline Kamini & Rutaceae & Murraya paniculata & Small tree \\
\hline
\end{tabular}




\begin{tabular}{lllc}
\hline Halde korobi & Apocynaceae & Thevetia peruviana & Small tree \\
Amloki & Phyllanthaceae & Phyllanthus emblica & Tree \\
Kanchan & Fabaceae & Piliostigma malabaricum & Small tree \\
Gutguttiya & Bureseraceae & Protium serratum & Tree \\
Buddha narikel & Malvaceae & Pterygota alata & Tree \\
Kanak & Theaceae & Schima wallichii & Tree \\
Udal & Malvaceae & Sterculia villosa & Tree \\
Dharmara & Bignoniaceae & Stereospermum perosonatum & Tree \\
Mahogoni & Meliaceae & Swietenia macrophylla & Tree \\
Dhakijam & Myrtaceae & Syzigum grande & Tree \\
Kalajam & Myrtaceae & S. cummini & Tree \\
Barajam & Myrtaceae & S. fruticosum & Tree \\
Golabjam & Myrtaceae & S. jambos & Tree \\
Chaltajam & Myrtaceae & S. megacarpum & Tree \\
Tetul & Fabaceae & Tamarindus indica & Tree \\
Segun & Verbenaceae & Tectona grandis & Tree \\
Nageswar & Calophyllaceae & Mesua ferra & Small tree \\
Bahera & Combretaceae & Terminalia bellirica, & Tree \\
Arjun & Combretaceae & T. arjuna & Tree \\
Toon & Meliaceae & Toona ciliate & Tree \\
Goda & Verbenaceae & Vitex peduncularis & Tree \\
Lohakat & Fabaceae & Xylia xylocarpa & Tree \\
Bon boroi & Rhamnaceae & Ziziphus rugosa & Small tree \\
Muli bans & Poaceae & Melocanna baccifera & Giant grass \\
\hline
\end{tabular}

Participatory map preparation by the local people

Participatory Rural Appraisal (PRA) technique may play an important role in planning the biodiversity conservation through people's participation. A participatory map of the Bihar mentioning different attributes was made by the local people and religious leaders. This map will be helpful for enrichment plantation and as well as to find out before and after plantation.

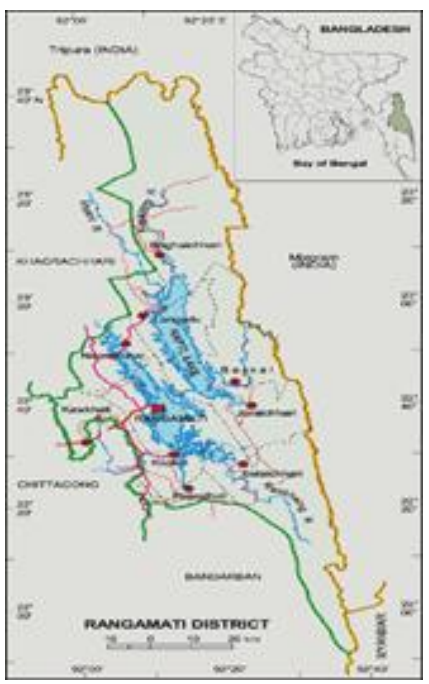

Fig. 1. Map of Rangamati District.

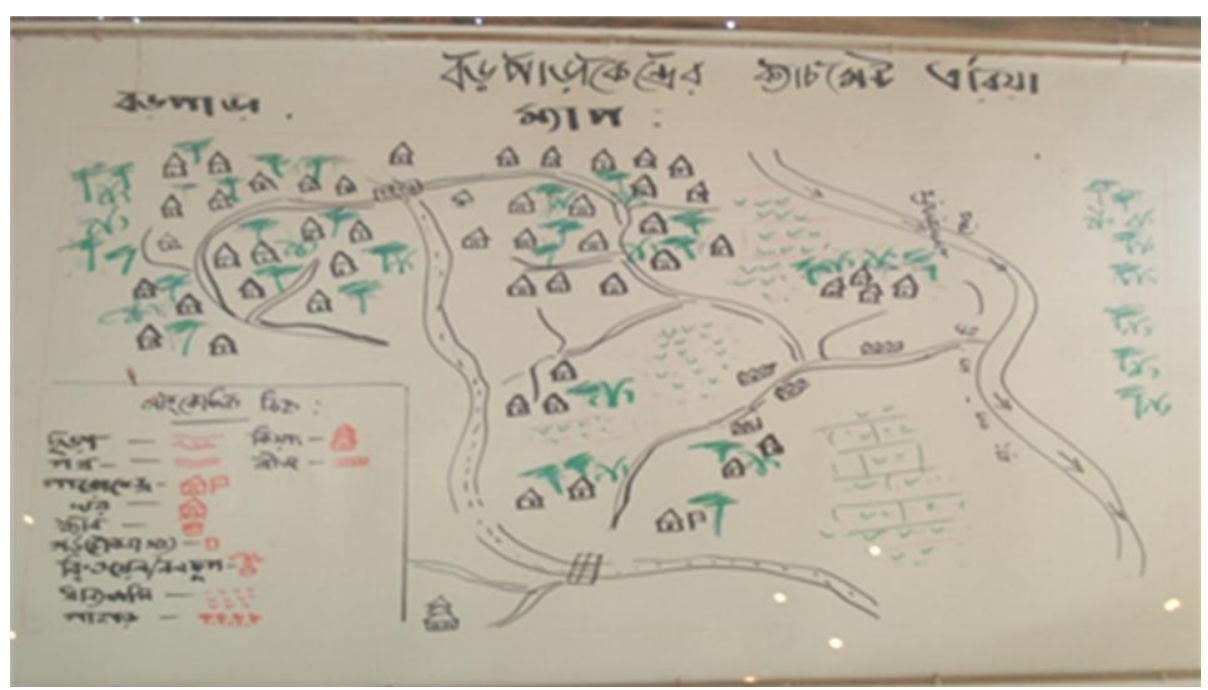

Fig. 2. PRA Map of Bihar area.

Species selection for enrichment plantation in Bihar areas

Discussion meeting was carried out with religious leaders, shrobon (trainees) and local people at Bodhipur Bonobihar, Khamarpara Adarsha Bonobihar and Nirbanpur Bihar about the importance of biodiversity conservation. Local people are not interested in deciduous plants in the Bihar area. These species do not retain water and make the soil dry. A priority species list of tree species has proposed for enrichment plantation around the Buddha-Bihar (Kiyang) area being consulted with the local people. 
Interesting feature is that the bantheyas are not interested in planting commercial fruit trees for religious point of view. The priority species list of trees is given in Table 2 .

Table 2. List of priority species of the study area.

\begin{tabular}{llll}
\hline Local Name & Scientific Name & Local Name & Scientific Name \\
\hline Champaful & Michelia champaca & Chikrassi & Chukrasia velutina \\
Sil-koroi & Albizia procera & Bot & Ficus benghalensis \\
Amloki & Phyllanthus emblica & Jarul & Lagerstroemia speciosa \\
Nagewasher & Mesua ferra & Bohera & Terminalia bellirica \\
Mahogani & Swietenia macrophylla & Krishna chura & Delonix regia \\
Dhaki-jam & Syzygium grandis & Neem & Azadirachata indica \\
Chapalish & Artocarpus chaplasha & Haritaki & Terminalia chebula \\
Garjan & Dipterocarpus spp. & Telsur & Hopea odorata \\
Banderhola & Dubanga grandiflora & Bet & Calamus guruba \\
Uriam & Mangifera sylvatica & Goda & Vitex pedunculari \\
Pitraj & Aphanamixis polystachya & Civit & Mangifera sylvatica \\
Bakul & Mimusops elengi & Batna & Quercus castanopsis \\
Borta & Artocarpus lacucha & Dakroom & Mitragyna parvifolia \\
\hline
\end{tabular}

Water retaining tree species in hill ecosystem

Big trees, shrubs and herbs are reserved the ground water. Religion leader and local people think that these species retain more water flow in the jhiri all over the year. These species are banderhola, pitraj,bot, dumur, painaturi, jam, bet, jogona etc. Also these tree species protect the soil from erosion.

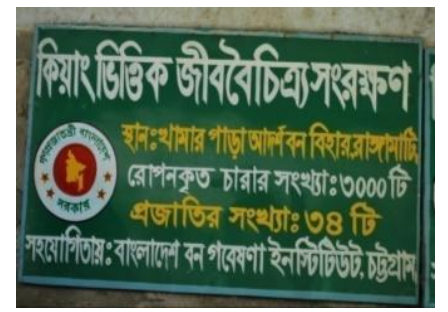

a.

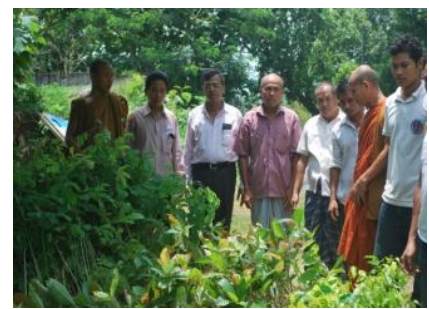

b.

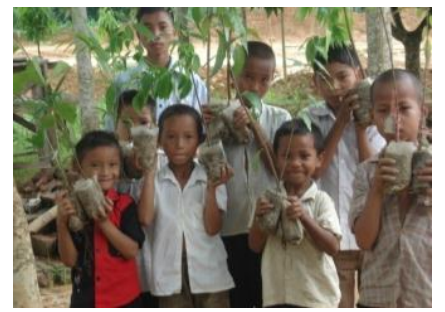

c.

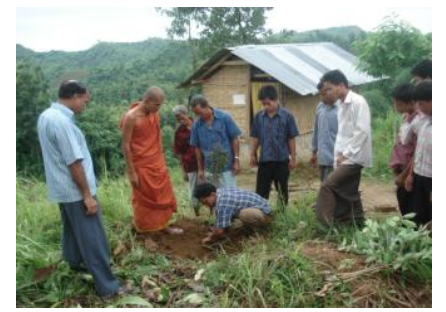

d.

Fig. 3. Plantation of seedling: a. Chart of seedling number, $\mathbf{b}$. distribution of seedling among people, $\mathbf{c}$. seedling carried by local children, and $\mathbf{d}$. plantation of seedling in Bihar area.

\section{Indigenous knowledge of religion leaders about plant species}

Religion leader and community people have lot of indigenous knowledge about plant species. They can identify the species using own knowledge and can classify in their local language. They also have traditional knowledge about forest tree species plantation and about their management. Most of the Bantheya like neem (Azadirachata indica) tree and they think the environment around the neem tree is healthy for human being. In Nirbanpur, two water tanks have been established using Gravitational Force System for continuous water supply in the Kiyang areas.

\section{Selective fruit tree cultivation in Bihar area}

The religion leaders are not interested in plant fruit trees in the bihar areas. They believe that fruit trees may derail the learners by eating fruit and this will from their main motive. But in some plain land areas some commercial fruit trees are planted for getting extra income.

\section{Awareness creation among the local people}

BFRI scientists conducted series of group meeting with the local people and religion leaders for awareness building. Group discussion activities have created positive awareness among the religious leaders and also among the local people for the indigenous tree species conservation in the Bihar areas. 
During the religious festival and ceremony, religious leaders give lecture on the importance of tree biodiversity conservation and motivate the local people towards biodiversity conservation.

BFRI efforts for supplying seedlings of Indigenous species

Twenty thousand seedlings of 32 indigenous tree species were distributed to three Bihar as per demand of local religion leaders. The supplied species were planted in the selected areas of Bihar as per their traditional knowledge. The important species were champaful (Michelia champaca), sil-koroi (Albizia procera), amloki (Phyllanthus emblica), nagewasher (Mesua nagassarium), khatbadam (Terminalia catappa), jarul (Lagerstroemia speciosa), putijam (Syzygium fruticosum), chikrassi (Chukrasia velutina), khayer (Acacia catechu), bohera (Terminalia bellirica), krishnachura (Delonix regia), mahogany (Swietenia macrophylla), lohakat (Xyliakerrii), neem (Azadirachata indica), chapalish (Artocarpus chaplasha), kadam (Anthocephalus chinensis), dhaki-jam (Syzygium grandis), haritaki (Terminalia chebula), motor-koroi (Albizia lucidor), amloki (Phyllanthus emblica), rain tree (Samanea saman), banderhola (Duabanga grandiflora), garjan (Dipterocarpus sp.), telsur (Hopea odorata) etc.

\section{Seedling planting in the Bihar area}

The local people have their own knowledge about tree plantation. They believed that they are the sons of forest and thus they have born knowledge about planting technique of forestry. So the seedlings were planted as per their desire and instruction of the bantheya. Male, female and children of the area cordially participated in the plantation program occasionally.

Biodiversity Conservation Model for Bihar

The bihar based biodiversity conservation model is based on four pillars.

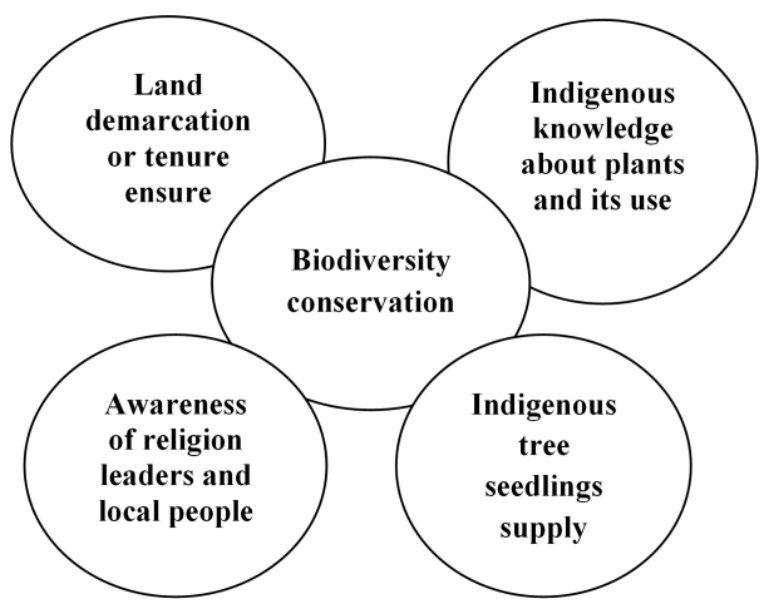

Community based management practices

The management practices of plantation around the bihar is not done by the hired labour. The local people manage the plantation willingly. Banthea demark the area of the Bihar and distribute the management work to the different para people. The para people do the management practices of plantation jointly during free time. This practice helps them to strengthen their bonding and also for biodiversity conservation. This type of community practices helps to develop ownership.

\section{Harbor for wildlife}

The wildlife habitat of Chittagong Hill Tracts is under tremendous threat due to forest degradation and destruction for a number of causes. Plantation of wild fruit trees has created a new safe habitat for the wild animals and birds. The bihar area is highly restricted for hunting from religious point of view, so animals and birds can move easily in this area. 
The biodiversity of the Kiyang will be enriched with indigenous tree species which can perform as conservation plot and future seed source. Buddha-Bihar (Kiyang) based biodiversity conservation will be helping protect watershed resources, soil fertility, soil moisture, and maintain ecological balance. Buddha-Bihar based biodiversity conservation has played a significant role in the in situ conservation of plant species. This programme has made the young generation especially, to understand the importance of biodiversity conservation, and to encourage local people to plant the tree species for the conservation of biodiversity and environment. Motivation of the local religion leaders and local people is the effective way for Kiyang based biodiversity conservation. Enrichment of plantation with the indigenous plant species may accelerate the conservation programme in the Kiyang or Bihar of Hill District of Bangladesh. This study proves that there are natural linkage between the Buddhist philosophy and biodiversity. If such trends are to continue, the world's religions should increase their concern and action on behalf of conservation.

\section{REFERENCES}

Alam, M. K. 1992. Medical ethnobotany of the Marma Tribe of Bangladesh. Econ. Bot. 46(3): 330-335.

Alam, M. K. 2008. Forests and Forestry in Bangladesh. In: Ahmed, Z. U., Z. N. T. Begum, M. A. Hassan, M. Khodker, S. M. H. Kabir, M. Ahmad, A. T. A. Ahmed, A. K. A. Rahman, and E. U. Haque (eds.). Encyclopedia of Flora and Fauna of Bangladesh. Vol. 1. Bangladesh Profile. Asiatic Society of Bangladesh, Dhaka, pp. 73-86.

Bellon, M. R. and S. B. Brush.1994. Keepers of Maize in Chiapas, Mexico. Econ. Bot. 48: 152-158.

Biswas, S. 1990. Ethno botanical studies on Northeastern Region of India with particular Emphasis on conservation of Biological Diversity. In: P. Shengji, S. Yong-ge, L. Chun-Lin, K. Marr and D. A. Possy (eds). The Challenges of the Second International Congress of Ethnobotany. Yunnan Science and Technology press, China, pp. 344-350.

Brush, S. B. 1991. A Farmer based Approach to Conserving Crop Germplasm. Econ. Bot. 45: 153-165.

Chakma, S., M. K. Hossain, B. M. Khan and M. A. Kabir. 2003. Ethno-botanical knowledge of Chakma community in the use of medicinal plants in Chittagong Hill Tracts, Bangladesh. MFP News. XIII(3): 3-7.

Chambers, R. 1992. Rural appraisal: rapid, relaxed and Participatory. IDS Discussion Paper No 311.

Das, D. K. and M. K. Alam. 2001. Trees of Bangladesh. Bangladesh Forest Research Institute, Chittagong, pp. 1-10.

Eken, G., L. Benun, T. M. Brooks, W. Darwall, L. D. C. Fishpool, M. Foster, D. Knox, P. Langhammer, P. Matiku, E. Radford, P. Salaman, W. Scherest, M. L. Smith, S. Spector and A. Tordoff. 2004. Key biodiversity areas as site conservation targets. Bioscience. 54: 1110-1118.

Haque, S. M. S. and M. S. Alam. 1988. Some aspects of practicing the clear felling followed by artificial regeneration system in the Cox's Bazar Forest Division. Chittagong Univ. Stud. Part II. 12(2): $87-$ 95.

Hassan, M. M. 1995. Biodiversity Conservation and Management in Bangladesh: A state of the Art. Review paper submitted to ICIMOD, Katmandu, Nepal.

Higgins, S. 2011. Conservation with Heart: Bridging Science and Religion., pp. 54-68

Kwit, C. and W. J. Platt. 2003. Disturbance history influences regeneration of non-pioneer under storey trees. Ecology. 84(10): 2575-2578.

Lakanavichian, S. 2000. The Buddhist Philosophy, Ecology and Biodiversity Conservation: Case Studies in Thailand: Links between Cultures and Biodiversity. Proceedings of the Cultures and Biodiversity Congress 2000. Yunnan, P. R. China, pp. 281-290. 
Lele, S., P. Wilshusen, D. Brockington, R. Seidler and K. Bawa. 2010. Beyond exclusion: alternative approaches to biodiversity conservation in the developing tropics. Curr. Opin. Environ. Sustain. 2: $1-7$.

Mohiuddin, M., M. K. Alam, S. R. Basak and M. K. Hossain. 2011. Ethnobotanical studies of the plant used by the tribals of Bandarban hill district, Bangladesh. Indian J. Forestry. 138(1): 84-89.

Mohiuddin, M., M. K. Alam, S. R. Basak and M. K. Hossain. 2012. Ethno-Medico Botanical of Bandarban Hill District in Bangladesh. Bangladesh J. Plant Taxon. 19(1): 45-53.

Primack, B. R. 1998. Essentials of Conservation Biology. 2nd ed. Sinauer Associates, 23 Plumtree Road, Sunderland, MA. USA. 659 pp.

Rahman, M. A. 1997. Tribal knowledge of plant use in Hill Tracts districts of Bangladesh. Biodiversity Newsletter. 1(1): 1 .

Rahman, M. A., S. B. Uddin and A. Khisha. 1998. A report on some anti-jaundice plants from tribal community of Hill Tracts districts. Biodiversity Newsletter. 2(1): 4.

Rahman, M. A., S. B. Uddin and C. C. Wilcock. 2003. Indigenous knowledge of herbal medicine in Bangladesh: Treatment of jaundice by the tribal community of Hill Tracts Districts. Hamdard Medicus. XLVI(2): 25-28.

Rajendran, A., K. Ravikumar and A. N. Henry. 1997. Utilisation of Wild Plant Resources for Food Consumption in Tamil Nadu. J. Non-Timber For. Products. 4(3/4): 93-95.

Rappaport, R. A. 1979. Ecology, Meaning and Religion. 2nd ed. North Atlantic Books. 272 pp.

Rappaport, R. A. 1999. Ritual and Religion in the Making of Humanity. Cambridge University. 535 pp.

Sandell, K. 1987. Philosophy and Inspiration for Eco-development. In: K. Sandell (ed). Buddhist Perspectives on the Ecocrisis. Buddhist Publication Society, Kandy, Sri Lanka. 76 pp.

Shaforth, P. B., J. C. Stromberg and D. T. Patten. 2002. Riparian vegetation response to altered disturbance and stress regimes. Ecol. Appl. 12: 107-123.

Soleri, D. and S. E. Smith. 1994. Morphological, phonological, and genetic comparisons of two maize varieties conserved in-situ and ex-situ. Presentation, Annual Meeting of the Societies for Economic Botany, Mexico City, 20-26 June.

Uddin, N. S., M. Z. Uddin, M. A. Hassan and M. M. Rahman. 2004. Preliminary ethnomedicinal plant survey in Khagrachari District, Bangladesh. Bangladesh J. Plant Taxon. 11(2): 39-48.

Uddin, S. B. and M. A. Rahman. 1998. Some anti-rheumatic plants used by tribal people of the Hill Tracts districts. Biodiversity Newsletter. 2(2): 4.

Yusuf, M., M. A. Rahman, J. U. Chowdhury and J. Begum. 2002. Indigenous knowledge about the use of zingibers in Bangladesh. J. Econ. Taxon. Bot. 26(3): 566-570.

Yusuf, M., M. A. Wahab, J. U. Chowdhury and J. Begum. 2005. Herbal treatment of Jaundice in Chittagong Hill Tracts by Chakma and Marma tribes. J. Forestry Environ. 3: 13-18.

Yusuf, M., M. A. Wahab, J. U. Chowdhury and J. Begum. 2006. Ethno-medico-botanical knowledge from Kaukhali proper and Betbunia of Rangamati district. Bangladesh J. Plant Taxon. 13(1): 55-61.

DOI: http://dx.doi.org/10.3329/jbcbm.v4i1.37874 